\title{
DOMINASI PEREMPUAN PEBISNIS DALAM RUMAH TANGGA
}

\author{
Ikhma Zurani \\ Universitas Riau, Pekanbaru, Indonesia. \\ ikhma.zurani@lecturer.unri.co.id
}

\begin{abstract}
Women as business people are no longer taboo and foreign for at least the past decade. The data shows an increase in the number of women as business people continues to increase from year to year no exception in the city of Pekanbaru. This research aims to find out how women's business domination in the household in Pekanbaru. The study used qualitative techniques with a phenomenological study approach and a constructivism paradigm. Some of the things that became the focus of the analysis in this study: how the dominance of women's decision-making entrepreneurs as wives in households and wife's efforts to preserve family harmony. Decision making in households is divided into three parts, namely: decision making for domestic household affairs; Decision-making in childcare affairs; and other important business decision making. The research results describe if in decision making for domestic affairs of households dominated by wives. Decision-making about parenting is a collaboration between husbands and wives. On the other hand, important decision making involving investment and business is dominated by wives. As a wife, there are several efforts to maintain household harmony including Pillow talk; Realizing the nature of sustenance; and supporting husbands form their own business.
\end{abstract}

Keyword: women's domination, family communication, gender

\begin{abstract}
Abstrak
Perempuan sebagai pebisnis bukan lagi menjadi hal tabu dan asing setidaknya selama satu dekade terakir. Data menunjukkan peningkatan jumlah perempuan sebagai pebisnis terus meningkat dari tahun ketahun tidak terkecuali di kota Pekanbaru. Penelitian ini bertujuan untuk mengetahui bagaimana dominasi perempuan pebisnis dalam rumah tangga di Pekanbaru. Penelitian ini menggunakan teknik kualitatif dengan pendekatan studi fenomenologi dan paradigma konstruktivis. Beberapa hal yang menjadi fokus analisa dalam penelitian ini: bagaimana dominasi pengambilan keputusan perempuan pebisnis sebagai istri dalam rumah tangga dan usaha istri untuk menjaga keharmonisan keluarga. Pengambilan keputusan dalam rumah tangga dibagi menjadi tiga bagian, yaitu: pengambilan keputusan untuk urusan domestik rumah tangga; pengambilan keputusan dalam urusan pengasuhan anak; dan pengambilan keputusan urusan penting lainnya. Hasil penelitian menggambarkan jika dalam pengambilan keputusan untuk urusan domestik rumah tangga didominasi oleh istri. Pengambilan keputusan mengenai pengasuhan anak merupakan kolaborasi suami dan isteri. Disisi lain, pengambilan keputusan penting yang menyangkut investasi dan bisnis lebih didominasi oleh istri. Sebagai isteri, ada beberapa usaha yang dilakukan untuk menjaga keharmonisan rumah tangga diantaranya: Pillow talk; menyadari hakikat rezeki; serta mendukung suami membentuk bisnisnya sendiri.
\end{abstract}

Kata Kunci: dominasi perempuan, komunikasi keluarga, gender

\section{PENDAHULUAN}

Hubungan peran (role relations) mengikat hampir semua orang didalam sebuah sistem hak dan kewajiban keluarga. Hubungan peran ini telah diajarkan sejak dini, sehingga setiap orang mengetahui apa yang dikehendaki dan diharapkan oleh anggota keluarga dari peran dalam konteks gender yang akhirnya menjadi tanggung jawab setiap individu. Misalnya saja, untuk pekerjaan domestik sudah sejak lama 
dilekatkan pada perempuan (Tuwu, 2018). Pola keluarga di Indoensia masih menjunjung tinggi sistem patriaki dimana peran dan tanggung jawab yang diembankan pada suami dan istri seolah-olah sudah pakem dan baku. Ketika seorang perempuan atau laki-laki memutuskan untuk melangkah bersama megarungi bahtera rumah tangga, mereka mempunyai standar tersendiri mengenai pasangan ideal. Selayaknya budaya timur yang mengedepankan bibit, bobot, bebet, hal tersebut yang menjadi pertimbangan dalam mencari pasangan hidup. Suami bertanggung jawab dalam pemenuhan kebutuhan rumah tangga, dan istri bertanggung jawab dalam pekerjaan rumah tangga (Nabilah Abdullah \& Wan Zulkifli Wan Hassan, 2010). Hampir setiap perempuan mendambakan pasangan yang mapan, humoris, pengertian, bisa diandalkan dan memiliki latar belakang keluarga yang baik. Namun pada kenyataannya, tidak sedikit perempuan harus kecewa lantaran tipe ideal dari seorang pasangan tidak mereka temukan dalam diri suaminya.

Menjalani kehidupan rumah tangga layaknya permainan roller coaster, ada masa dimana kita berada dipuncak, sementara di waktu lain kondisi menukik ke bawah. Suami dan isteri memiliki hak dan kewajiban yang harus dipenuhi agar kehidupan rumah tangga berjalan stabil (Salampessy, 2004). Idealnya, suami adalah pencari nafkah utama sementara istri bertugas mengurusi rumah tangga. Dengan semakin pesatnya perkembangan zaman, pertumbuhan ekonomi dan perkembangan teknologi informasi, tuntutan hidup mengalami perubahan menjadi semakin rumit, kompleks dan tinggi. Hal inilah yang menjadi salah satu penyebab perempuan memutuskan untuk bekerja atau membangun bisnis. Tidak sedikit yang memulainya dari masa sebelum menikah atau lajang. Pandangan tradisional yang mewajibkan seorang perempuan atau isteri harus dirumah semakin memudar. Kondisi ini merupakan efek dari industrialisasi dan globalisasi yang memudarkan ideologi dan batas-batas budaya sebuah bangsa dalam
(Ihromi, 2006). Penelitian yang dilakukan oleh F. Paputungan dan kawan-kawan dalam artikel jurnal yang berjudul "Kepuasan Pernikahan Suami yang Memiliki Istri Berkarir" (Paputungan, Akhrani, \& Pratiwi, 2013). Hasil Penelitian menunjukkan bahwa subjek penelitian merasa kurang puas dengan pernikahannya, terutama dalam keintiman fisik. Kepuasan pernikahan bisa tercapai jika suami istri mampu menciptakan komunikasi yang konstruktif dan terbuka; komitmen; kepuasan pada faktor kongruensi; dan keyakinan beragama dalam pernikahan.

Di lain pihak, penelitian yang dilakukan oleh Triana dan kawan-kawan, yang dimuat dalam artikel jurnal yang berjudul "Peran Ganda Ibu Rumah Tangga Pekerja K3L UNPAD dalam Rangga Menunjang Perekonomian Keluarga" (Triana \& Krisnani, 2018). menunjukkan bahwa ibu rumah tangga pekerja K3L yang menjadi subjek penelitian mampu menjalani peran sebagai pekerja dan ibu rumah tangga dengan baik. Walaupun mereka bekerja, tetapi tanggung jawab dan tugas sebagai ibu rumah tangga tetap terpenuhi.

Perempuan-perempuan yang mandiri secara finansial menimbulkan fenomena unik, yaitu bergesernya posisi tulang punggung finansial keluarga dari pundak suami ke pundak isteri Era globalisasi yang mendukung kondisi ini diperkirakan akan menghasilkan tiga kemungkinan, yaitu; peran perempuan memudar, keajegan penajaman peran laki-laki dan tidak jelas lagi pembeda antar keduanya (Uci Yuliati, 2019). Kondisi ini menimbulkan konflik tersendiri yang didukung oleh budaya patriarki masih langgeng berkembang di tatanan masyarakat Indonesia (Sakina \& A., 2017). Walaupun mungkin perempuan dibesarkan di lingkungan keluarga yang moderat, tetapi masyarakat luas secara umum masih menganggap kondisi ini sebagai kondisi yang aneh atau tidak semestinya. Penelitian yang dilakukan oleh Kate Ratliff, $\mathrm{PhD}$, dari Universitas California menyatakan bawah lakilaki terusik egonya, merasa minder, bersalah 
dan gagal dalam menjalankan perannya sebagai suami ketika isteri memiliki penghasilan lebih besar atau memiliki karir yang lebih cemerlang dibandingkan dirinya. Kondisi tersebut sangat berpeluang menimbulkan konflik, baik dalam diri maupun keluarga (Kompasiana, 2015)

Survei yang dilakukan World Value memaparkan bahawa ada beberapa masalah yang timbul ketika istri memiliki karir dan pendapatan yang lebih besar dibandingkan suami, seperti perasan kurang bahagia sehingga menimbulkan gesekan perselisihan dalam rumah tangga, bahkan dalam beberapa kasus berujung pada perceraian (Kompasiana, 2015). Bahkan ketika istri lebih dominan dalam pengambilan keputusan, ternyata persepsi dan corak relasi antar suami dan istri telah berubah. Merasa kalah dengan istri menjadi beban yang tanpa disadari dipikul oleh suami, padahal mereka tidak sedang berkompetisi dengan sang istri.

Disisi lain, kondisi perempuan yang menopang finansial keluarga diduga juga membawa pergeseran peran laki-laki dalam keluarga. Rumah tangga dengan istri sebagai penyokong finansial diduga mempunyai suami yang lebih egaliter, yang berarti laki-laki lebih banyak terlibat dalam urusan domestik rumah tangga dan keputusan-keputusan penting dalam rumah tangga didominasi oleh istri.

Pekanbaru sebagai ibukota Provinsi Riau juga tidak luput dari fenomena ini. Hasil observasi peneliti menunjukkan semakin banyak perempuan yang akhirnya memilih terjun ke dunia bisnis dan mencari pekerjaan dengan berbagai macam alasan. Sebagai contoh, peneliti tergabung dalam kelompok UMKM yang ada di Kota Pekanbaru dan dari penelusuran peneliti menemukan $65 \%$ pemilik usaha tersebut adalah perempuan. Tidak hanya tergabung dalam group UMKM, peneliti juga melihat langsung dominasi jumlah perempuan di kampus tempat peneliti mengajar.

Penelitian ini menggunakan pendekatan fenomenologi dan paradigma konstruktivis karena dengan menggunakan keduanya peneliti dapat menganalisis dominasi istri penyokong finansial dalam pengambilan keputusan rumah tangga dari sudut komunikasi, serta bagaimana usaha istri untuk mempertahankan rumah tangga yang harmonis. Penelitian ini menggunakan teori Gender dan teori kontruktivisme, dimana konstruktivis mempunyai pandangan bahwa fenomena yang terjadi didunia dapat di pahami dan di intrepretasikan dengan cara yang berbeda dan sempurna sedangkan gender secara teori dapat diartikan sebagai pembeda peran, hubungan dan identitas antara lakilaki dan perempuan yang merupakan hasil bentukan masyarakat, Penelitian ini diharapkan memberikan manfaat teroritis maupun praktis. Secara teoritis, penelitian ini diharapkan dapat memperkaya penelitian kualitatif, khususnya dalam konteks gender dan komunikasi yang terkait dengan dominasi perempuan pebisnis mengambil keputusan dalam rumah tangga dari sudut pandang fenomenologi. Kegunaan praktis dalam penelitian ini berupa hasil analisis pengalaman komunikasi individu dalam keluarga dimana istri lebih berperan penting dalam menyokong finansial keluarga. Analisa tersebut dapat dijadikan pedoman bagi bidang gender komunikasi, dimana dalam keluarga peran istri lebih dominan untuk memenuhi kebutuhan finansial keluarga. Bagi masyarakat umum, analisa penelitian ini dapat menjadi pedoman untuk memahami dan menerima kondisi keluarga yang sosok istri merupakan penyokong utama finansial keluarga.

Teori konstruktivis atau sering juga disebut teori konstruktivisme dalam penelitian ini dapat digunakan untuk menggambarkan bagaimana dominasi perempuan pebisnis dalam pengambilan keputusan di rumah tangga. Teori konstruktivis dapat digunakan untuk membaca realitas sikap santri multibudaya dalam memaknai pesan yang di komunikasikan kyai dalam aktivitas pendidikan multikultural di pondok pesantren. Teori konstruktivis atau konstruktivisme dinilai sebagai makna yang sama. Sebagai sebuah teori, menurut Littlejohn (2014:25), konstruktivisme percaya bahwa 
orang yang menciptakan pengetahuan agar dapat berjalan secara pragmatis di dunia bahwa fenomena dapat dipahami dalam cara yang berbeda dan sempurna bahwa pengetahuan adalah apa yang dihasilkan dari seseorang di dunia ("mereka bukan apaapa hingga saya menyebutkannya"). Akhirnya membawa konstruktivisme selangkah lebih jauh, konstruktivisme sosial mengajarkan bahwa pengetahuan merupakan produk interaksi sosial simbolis dalam kelompok-kelompok sosial. Dengan kata lain, kenyataan terbentuk secara sosial, sebuah hasil kehidupan kultural dan kelompok.

Berdasarkan definisi tersebuti, teori konstruktifis menjelaskan dua hal penting. Pertama, bahwa setiap manusia menciptakan pengetahuannya sendirisendiri agar mereka dapat hidup di dunia. Kedua, pengetahuan yang didapatkan tersebut untuk bertahan hidup itu sejatinya bukanlah hasil kreasinya sendirinya, melainkan hasil dari interaksi sosial dengan orang lain, yakni kehidupan kultural dan kelompok yang mempengaruhi seseorang tersebut bertindak. Untuk mempertegas teori ini, Littlejohn mencontohkan sebuah kasus wasit, pengetahuan tentang apa itu bola dan pukulan hanya dapat diketahui dalam kerangka permainan baseball, serta dalam kedua istilah tersebut, bola dan pukulan memiliki banyak arti lain dalam bahasa Inggris yang cukup berbeda dalam permainan baseball.

Dalam kehidupan berumah tangga, masing-masing individu terutama suami istri menciptakan pengetahuannya sendiri agar dapat menjalani kehidupan rumah tangga. Kemampuan bertahan dengan lingkungan baru yang jelas sangat berbeda dengan lingkungan sebelum mereka memasuki rumah tangga. Sering kali terdapat perbedaan ekspektasi tentang rumah tangga dengan kenyataan yang dijalani memaksa individu merekonstruksi kembali bagaimana peran masing-masing anggota keluarga.

Gender merupakan konstruksi sosio-kultural yang membagi karakteristik menjadi maskulin dan feminine. Makna gender tidak berarti mutlak sama dengan jenis kelamin laki-laki dan perempuan yang merupakan pembagian berdasarkan biologis, walaupun jeis kelamin perempuan sering dihubungkan dengan gender feminin, begitu juga dengan jenis kelamin laki-laki, sering dihubungkan dengan gender maskulin. Gender secara teori dapat diartikan sebagai pembeda peran, hubungan dan identitas antara laki-laki dan perempuan yang merupakan hasil bentukan masyarakat (Fakih, 2004).

Ketidakseimbangan yang dilihat dari sudut pandang gender merupakan ketidakseimbangan akses ke sumber-sumber penting, yang meliputi keleluasaan waktu, penentuan peran, jasa yang diberikan orang lain, kekuasaan barang material, prestise, akses memperoleh pendidikan dan pelatihan serta kebebasan dari paksaan atau siksaan fisik (Budiman, 1982:26). Antara laki-laki dan perempuan terdapat perbedaan gender (gender differences) telah berlangsung dari masa ke masa yang tertulis dalam sejarah, disosialisasikan turun temurun dalam jangka waktu yang sangat panjang dan kompleks, serta diperkuat dan dikonstruksikan secara sosial sehingga dipandang sebagai kodrat yang ditentukan oleh Tuhan (Fakih, 1996:15). Selain itu, terdapat perbedaan perlakuan dalam pengaturan syarat kerja dan permasalahan kesetaraan gender dalam dunia kerja dipengaruhi oleh faktor-faktor seperti, marginalisasi, subordinasi, stereotipe, violence, dan beban kerja (Effendi \& Ratnasari, 2018).

Perbedaan biologis yang sering dikaitkan dengan gender menjadikannya digunakan untuk menentukan relati gender, seperti pembagian hak dan kewajiban, fungsi, peran, dan status dalam masyarakat. Lebih jauh lagi, keterkaitan fungsi dan peran antara perempuan dan lakilaki sangat berpengaruh dalam keutuhan masyarakat. Hal inilah yang menyebabkan sistem patriarki dimana peran laki-laki lebih menonjol dari pada perempuan menjadi sesuatu hal yang wajar. Pembagian peran inilah yang kemudian membuat perempuan 
juga mendapat stereotype dari berbagai institusi baik dalam karir, ekonomi, dan juga pendidikan merupakan hasil dari Pembagian peran tersebut (Ayu, 2017).

Dalam relasi gender, skor laki-laki lebih unggul daripada perempuan dalam penentuan norma-norma kehidupan masyarakat. dapat dicontohkan pada perempuan dituntut untuk lebih berhati-hati dalam membawa diri, sedangkan laki-laki memiliki otoritas untuk menampilkan diri lebih terbuka.

Sedikit berlawanan dengan teori gender yang telah ada, penelitian yang dilakukan F. Ivan Nye sangat menarik, ia menyatakan bahwa terdapat lima kelompok opini masyarakat mengenai fungsi dan peran suami istri, yaitu: segalanya pada suami; suami melebihi peran istri; suami dan istri memiliki peran yang sama; peran istri melebihi peran suami; dan yang terakhir adalah segalanya pada istri (Nye dalam Umar, 1999:15). Hasil penelitian ini menunjukkan telah terjadi perubahan besar dalam masyarakat dan tantangan terhadap teori ini semakin besar untuk masa yang akan datang.

Era globalisasi seperti saat ini menjadikan pembagian fungsi dan peran antara suami istri sesuai dengan teori gender sulit dipertahankan. Daya saing dan keterampilan (meritokration) menjadi aspek yang lebih dipertimbangkan dibandingkan jenis kelamin. Laki-laki dan perempuang memiliki peluang yang sama dalam persaingan. Berkaitan dengan perempuan yang memiliki karir, ternyata Survei yang dilakukan oleh perusahaan Randstad tahun 2012 menunjukkan bahwa pekerja wanita mengutamakan terciptanya work-life balance, dibandingkan laki-laki yang terfokus pada peluang kemajuan karir (Bintang \& Astiti, 2016).

Penelitian ini menggunakan pendekatan fenomenologi dan metode penelitian kualitatif untuk menggambarkan pengalaman dominasi istri bekerja yang berperan sebagai penyokong utama finansial keluarga dalam pengambilan keputusan rumah tangga. Pengalaman ini berkaitan dengan pengambilan keputusan dalam rumah tangga yang didominasi oleh perempuan dan bagaimana usaha perempuan dalam menjaga keharmonisan keluarganya. Littejohn menyatakan bahwa pengalaman sadar individu merupakan fokus dari tradisi fenomenologi. Pengalaman pribadi secara aktif di interpretasikan oleh individu dalam proses memahami kehidupan (2005:38).

Aliran konstruktivisme menyatakan bahwa realitas itu ada dalam beragam bentuk konstruksi mental yang didasarkan pada oengalaman sosial, bersifat local dan spesifik, serta tergantung pada pihak yang melakukannya. Oleh karena itu, sebuah realitas yang diamati oleh peneliti tidak bisa digeneralisasikan kepada semua orang. Dalam paradigma, hubungan antara pengamat dan objek merupakan satu kesatuan, subjektif dan merupakan hasil perpaduan interaksi antar keduanya (Moleong, 2010:70).

Paradigma konstruktivisme memiliki beberapa kriteria yang membedakannya dengan paradigma lainnya, yaitu secara ontologi, epistimologi, dan metodologi. Secara ontologi, paradigma konstruktivisme melihat kenyataan sebagai hal yang ada tetapi realitas bersifat majemuk dan memiliki makna yang berbeda bagi setiap orang. Secara epistemologi, peneliti menggunakan pendekatan subjektif karena dengan cara itu bisa menjabarkan pengonstruksian makna oleh individu. Secara metodologi, paradigma kosntruktivisme menggunakan berbagai macam jenis pengkonstruksian dan menggabungkannya dalam sebuah konsensus.

Dalam penelitian ini penulis menggunakan paradigma konstruktivisme. Konstruktivisme meneguhkan asumsi bahwa individu-individu selalu berusaha memahami dunia dimana mereka hidup. Mereka mengembangkan maknamakna subjektif atas pengalaman-pengalaman mereka, makna-makna yang diarahkan pada objek atau benda tertentu. Makna-makna ini pun cukup banyak dan beragam sehingga peneliti dituntut untuk lebih mencari kompleksitas pendangan ketimbang mempersempti makna menjadi sejumlah kategori dan gagasan. Untuk 
mengeksplorasi pandangan-pandangan ini, pertanyaan-pertanyaan pun perlu diajukan. Pertanyaan ini bisa sangat luas dan umum sehingga partisipan dapat mengkonstruksi makna atas situasi tersebut, yang biasanya tidak asli atau tidak dipakai dalam interaksi dengan institusi lain. Semakin terbuka pernyataan tersebut tentu akan semakin baik, agar peneliti bisa mendengarkan dengan cermat apa yang dibicarakan dan dilakukan partisipan dalam perusahaan mereka.

Peneliti menggunakan pendekatan fenomenologi dan paradigman konstruktivis karena dengan menggunakan keduanya peneliti dapat menganalisis dominasi istri penyokong finansial dalam pengambilan keputusan rumah tangga dari sudut komunikasi, serta bagaimana usaha istri untuk mempertahankan rumah tangga yang harmonis.

\section{METODOLOGI}

Paradigma yang digunakan dalam penelitian ini adalah paradigma konstruktivisme dengan metode Fenomenologi. Adapun berbagai definisi dalam konstruktivisme oleh para ahli. Menurut Denzin \& Lincoln (2009), dikatakan juga bahwa konstruktivisme mengadopsi ontologi relativisme, epistemologi transaksional, dan metodologi hermeneutik atau dialektik. Dalam pengertian selanjutnya Deddy Mulyana menyebutkan pendekatan fenomenologi termasuk pada pendekatan yang bersifat subjektif atau interpretif (Mulyana, 2018:59).

Tujuan utama fenomenologi adalah mempelajari bagaimana fenomena di alami dalam kesadaran, pikiran dan dalam tindakan, seperti bagaimana fenomena tersebut bernilai dan diterima secara estetis (Kuswarno, 2013:3537). Jadi, dengan fenomenologi kita dapat mencari bagaimana manusia mengkontruksi makna dan konsep-konsep penting yang terbentuk melalui hubungan kita dengan orang lain.

Feneomenologi bertujuan untuk mengetahui dunia dari sudut padang orang yang mengalaminya secara langsung atau berkaitan dengan sifat-sifat alami pengalaman manusia dan makna yang ditempelkan padanya.. Maka itu, penelitian dengan metode ini harus menunda proses penyimpulan mengenai sebuah fenomena. Oleh karena itu, fenomenologi sebagai metode penelitian tidak menggunakan hipotesis untuk di uji lebih lanjut dan tidak bertujuan untuk menguji teori.

Penelitian ini menggunakan Teori Gender dan Teori Kontruktivisme, dimana konstruktivis mempunyai pandangan bahwa fenomena yang terjadi didunia dapat di pahami dan di intrepretasikan dengan cara yang berbeda dan sempurna sedangkan gender secara teori dapat diartikan sebagai pembeda peran, hubungan dan identitas antara laki-laki dan perempuan yang merupakan hasil bentukan masyarakat, Penelitian ini diharapkan memberikan manfaat teroritis maupun praktis. Secara teoritis, penelitian ini diharapkan dapat memperkaya penelitian kualitatif, khususnya dalam konteks gender dan komunikasi yang terkait dengan dominasi perempuan pebisnis mengambil keputusan dalam rumah tangga dari sudut pandang fenomenologi. Kegunaan praktis dalam penelitian ini berupa hasil analisis pengalaman komunikasi individu dalam keluarga dimana istri lebih berperan penting dalam menyokong finansial keluarga. Analisa tersebut dapat dijadikan pedoman bagi bidang gender komunikasi, dimana dalam keluarga peran istri lebih dominan untuk memenuhi kebutuhan finansial keluarga. Bagi masyarakat umum, analisa penelitian ini dapat menjadi pedoman untuk memahami dan menerima kondisi keluarga yang sosok istri merupakan penyokong utama finansial keluarga.

\section{HASIL DAN PEMBAHASAN}

Penelitian ini membagi pengambilan keputusan dalam rumah tangga menjadi tiga bagian yaitu: pengerjaan urusan domestik rumah tangga; perawatan anak; dan pengambilan keputusan pentingnya dalam rumah tangga. 
Selain itu penelitian ini juga menganalisa usaha informan selaku istri dalam mempertahankan keharmonisan keluarga.

Informan merupakan perempuan yang memiliki dan mengelola bisnis sendiri tentu dituntut untuk bisa mengelola waktu antara uturan bisnis dan urusan rumah tangga. Mengambil alih tanggung jawab finansial bagi istri merupakan satu bentuk kerja sama partnership dalam rumah tangga. Banyaknya urusan domestik rumah tangga dan urusan bisnis, sementara waktu yang dimiliki terbatas, menjadikan informan harus membuat skala prioritas tentang urusan yang harus dikerjakan terlebih dahulu, urusan yang dikerjakan belakangan, dan urusan yang bisa didelegasikan oleh orang lain.

Berdasarkan kondisitersebut, maka informan selaku istri memutuskan untuk mendelegasikan sebagian besar urusan domestik rumah tangga kepada orang lain. Misalnya urusan membersihkan rumah didelegasikan ke asisten rumah tangga, menyetrika kepada provider laundry dan ketersediaan makanan tinggal dibeli online atau offline dari restoran kesukaan keluarga. Akan tetapi bukan berarti istri sama sekali tidak mengerjakan pekerjaan rumah tangga sama sekali, diwaktu luang maka istri memasak makanan kesukaan keluarga, hanya saja tujuan dari kegiatan ini bukan sekedar menyajikan makanan saja, tetapi membangun kebersamaan dan menguatkan cinta dan kasih sayang dalam keluarga. Menyadari bahwa dalam kehidupan sebagai suami isteri diperlukan pengorbanan agar kehidupan keluarga berjalan hermonis (Yahaya, 2008).

Keputusan pendelegasian urusan domestik rumah tangga tersebut merupakan usulan informan selaku istri yang didukung suami. Suami memaklumi keterbatasan istri dalam mengerjakan urusan domestik rumah tangga, bahkan suami terkadang dengan sukarela membantu urusan domestik. Bagi istri hal tersebut bukan sekedar bantuan penyelesaian urusan rumah tangga, tetapi bentuk romantisme suami terhadap istri. Tidak jarang suami, istri, dan anak-anak mengerjakan pekerjaan rumah tangga bersama seperti membersihkan halaman, mencuci mobil dan sebagainya sebagai sarana rekreasi yang mengakrabkan dan menghangatkan keluarga.

Jika untuk urusan domestik rumah tangga istri memutusakan untuk mendelegasikan sebagian besar kepada orang lain, tetapi tidak untuk urusan pengasuhan anak. Pengasuhan anak tetap dipegang penuh oleh kedua orangtua. Dalam menjalani relasi suami-istri, konsep kerja sama dan partnership sangat dikedepankan, terutama dalam pengasuhan anak. Ketika istri tidak bisa hadir secara fisik dalam membersamai anak, maka suami akan menggantikan, begitu juga sebaliknya, ketika suami memiliki urusan tertentu, maka istri akan menggantikannya. Hal ini dilakukan agar anak tidak kehilangan kasih sayang dari sosok orangtuanya.

Dalam kasus informan dalam penelitian ini, beberapa urusan penting lainnya yang menyangkut anak lebih didominasi oleh suami. Misalnya tentang pemilihan sekolah anak. Suami mengusulkan pilihannya dan informan sebagai istri biasanya menyetujui pilihan suaminya.

Untuk keputusan penting lainnya, istri memiliki dominasi yang cukup signifikan, terutama keputusan yang berkaitan dengan bisnis dan investasi. Walaupun demikian, istri tetap berdikusi terlebih dahulu dengan suami sebelum keputusan tersebut dilaksanakan. Bagi istri, selain sebagai partner dalam hidup, suami juga imam dalam rumah tangga, sehingga sebelum memutuskan urusan yang penting, pertimbangan dan persetujuan suami sangatlah penting. Di pihak suami, munculnya kepercayaan atas kemampuan istri sehingga untuk urusan bisnis dan investasi, ia lebih menekankan pada hal-hal yang bersifat legalitas. Lebih lanjut lagi, pandangan objektif tentang urgensi keputusan akan dilakukan atau tidak lebih banyak datang dari suami. Tingkat pendidikan suami dan isteri, asset, pendapat mempengaruhi manajemen sumberdaya 
keluarga yang meliputi perencanaan, pembagian tugas, dan pengawasan (Iskandar, 2007).

Bagi informan, bersama-sama mencari nafkah merupakan salah satu bentuk kerja sama dalam keluarga, walaun pada kenyataannya penghasil istri yang lebih dominan dalam pemenuhan kebutuhan rumah tangga. Suami yang tidak memaksa informan mengerjakan urusan domestik rumah tangga, serta ringan tangan dalam urusan pengasuhan anak merupakan suatu bentuk kompensasi bagi istri. Lebih dari itu, hal ini merupakan wujud dari saling mengisi dalam rumah tangga.

Informan dalam penelitian ini menyadari sepenunya bahwa pola rumahtangga yang mereka jalani tentu memiliki resiko lebih besar daripada keluarga normal (suami bekerja) lainnya. Tidak sedikit kerabat dan kenalan informan yang juga sebagai pencari nafkah utama dalam kelurga berakhir pada perceraian. Hal ini tidak lepas dari stigma masyarakat yang begitu kuat mengangkat pola pikir dan tindakan suami istri dimana suami tetap sebagai pemimpin dalam setiap rumahtangga. Istri belajar memahami bahwa se-egalitrenya seorang suami, ia tetaplah seorang laki-laki yang mempnyai ego tersendiri. Menjaga agar ego suami tidak terluka menurut informan adalah kunci agar rumah tangganya tetap harmonis. Walau tentu saja, seperli layaknya rumah tangga lainnya, pertengkaran kerap hadir, tetapi masih dalam kondisi wajar menurut informan. Perempuan memang memiliki orientasi masa depan (future oriented) atau cenderung lebih berpandangan ke masa depan ketika akan membuat suatu keputusan dan bertindak dibandingkan dengan lelaki (Sherlywati, Handayani, \& Harianti, 2017).

Pada akirnya, dalam sistem keluarga dimana istri lebih dominan untuk urusan mencari nafkah membuat pasangan suami istri mau tidak mau belajar menyesuaikan dan memahami pergeseran peran ini. Suami belajar menerima konsekuensi untuk bisa lebih banyak mengurusi hal domestick dalam rumah tangga sementara istri bertanggung jawab dalam pemenuhan kebutuhan hidup keluarga. Informan dalam penelitian ini membuktikan bahwa proses adaptasi pola ini memang tidak mudah, namun peran dan status sebagai suami dan istri tetap berjalan cukup baik meski istri mendominasi dalam urusan mencari nafkah.

Pillow talk, yaitu percakapan sebelum tidur merupakan strategi penyelesaian konflik yang paling dominan dilakukan informan pada penelitian ini. Dibutuhkan sikap saling terbuka dan hati yang lapang untuk menrima masukan dan kritikan dari pasangan. Pillow talk yang biasanya dilakukan pada malam atau pagi hari atau disaat-saat senggang suami istri terbukti sangat efektif mengurai keteganganketegangan yang timbul antara suami istri. Tidak bisa dipungkiri, kondisi istri sebagai pencari nafkah utama yang mengelola dan menjalankan bisnisnya secara mandiri telah memukul ego suami. Percikan konflik dan kesalahpahaman menjadi makanan sehari-hari, saat suami menuntut haknya dan begitu jusga sebaliknya dengan istri. Pada akirnya, keluarga akan lebih kokoh jika anggota keluarga bisa berkomunikasi efektif, sehingga seluruh keluarga merasa dirinya dicintai, dihargai, dikasihi, dan dimuliakan (Asiah, Irkhaniza, \& Mohamed Sharif, 2008).

Salah satu point utama yang mampu membuat pola komunikasi keluarga dengan istri sebagai pebisnis dan pencari nafkah utama adalah peranan aihromigama. Informan dalam penelitian ini beragama islam dan dalam islam ditetapkan beberapa ketentuan dan nilainilai yang mendasari sikap dan pemahaman dalam kehidupan termasuk soal rezeki. Istri menyadari bahwa rezeki yang didapatnya saat ini merupkan istri suami dan anak yang dititipkan Allah melaluinya. Nilai-nilai agama menjadi pagar pembatas yang mencoba menjaga istri untuk tidak meningkatkan ego dan superioritasnya dalam keluarga kususnya dalam hubungannya dengan suami. Jika informan tidak membungkus hal tersebut dengan sikap tawakal terhadap rezeki yang telah ditetapkan Allah, mungkin nasib rumahtangga informan 
tidak berbeda dengan beberapa rekannya yang berakhir dengan perceraian, bahkan ia berusaha menjaga integritas suami dimata orang-orang yang memandang suaminya miring. Kerukunan menjadi pedoman utama dalam hubungan suami isteri (Purbasari \& Putri, 2015).

Akhirnya, penulis menemukan informan dalam penelitian ini yakni perempuan pebisnis mendorong suaminya untuk membangun bisnis bersama atau malah membangun bisnis sendiri. Hal ini bertujuan agar ego dan superioritas suami dimata keluarga dan anak-anak tetap terjaga. Beberapa informan dalam penelitian ini malah mengajak suaminya untuk membantu mengelola bisnis mereka secara tidak langsung ataupun langsung.

\section{SIMPULAN}

Terdapat tiga dimensi yang terkait dalam pengambilan keputusan dalam rumah tangga. Dominasi istri pebisnis yang menyokong finansial keluarga ternyata tidak menyeluruh disemua dimensi. Ketiga dimensi itu adalah : 1) Untuk pengambilan keputusan urusan domestik rumah tangga didomninasi oleh istri yang disetujui oleh suami; 2) Urusan pengamambilan keputusan yang berkaitan dengan pengasuhan anak dilakukan bersama, anak tetapi dalam beberapa aspek lebih didominasi oleh suami; 3) Untuk pengambilan keputusan penting lainnya seperti urusan bisnis dan investasi lebih didominasi oleh istri.

Usaha yang dilakukan istri dalam menjaga keharmonisan keluarga antara lain: 1) Menjalin komunikasi efektif, misalnya dengan pillow talk, tentang apa yang dirasakan dan dialami, tentang keluarga hingga bisnis; 2) Menyadari dengan sepenuhnya jika rezeki yang datang lewat isteri merupakan rezeki suami dan anakanak; 3) serta mendukung suami membentuk bisnisnya sendiri.

\section{DAFTAR PUSTAKA}

Asiah, A., Irkhaniza, M. R., \& Mohamed Sharif, M. (2008). Peranan komunikasi dalam hubungan kekeluargaan. Seminar Kaunseling Keluarga, 82-89.

Ayu, R. K. (2017). Perempuan Pebisnis Startupdi Indonesia dalam Perspektif Cybertopia. Jurnal Studi Komunikasi (Indonesian Journal of Communications Studies). https://doi.org/10.25139/jsk.v1i2.167

Bintang, S. K., \& Astiti, D. P. (2016). WorkLife Balance Dan Intensi Turnover Pada Pekerja Wanita Bali Di Desa Adat Sading, Mangupura, Badung. Jurnal Psikologi Udayana, 3(3), 382-394.

Budiman, A. (1982). Pembagian Kerja Secara Seksual. Jakarta: Gramedia.

Denzin, N. K. \& Yvonna S. L. (2009). Handbook of Qualitative Research. Yogyakarta: Pustaka Pelajar.

Effendi, P., \& Ratnasari, D. (2018). Kesetaraan Gender Dalam Prespektif UndangUndang Nomor 13 Tahun 2003 Tentang Ketenagakerjaan. Jurnal Pro Hukum : Jurnal Penelitian Bidang Hukum Universitas Gresik.

Fakih, Mansour. 2004. Analisis Gender \& Transformasi Sosial. Yogyakarta: Pustaka Belajar.

Ihromi. (2006). Pokok-Pokok Antropologi Budaya. Jakarta: Yayasan Obor Indonesia.

Iskandar, A. (2007). Analisis Praktik Manajemen Sumberdaya Keluarga dan Dampaknya Terhadap Kesejahteraan Keluarga di Kabupaten da Kota Bogor. Sodality: Jurnal Sosiologi Pedesaan. https://doi.org/10.22500/sodality. v1i3.5924.

Kompasiana. (2015). Ketika penghasilan istri lebihtinggidarisuami.Diaksesdarihttp:// www.kompasiana.com/pakcah/ketikapenghasilan-istri-lebih-tinggi-darisuami_54f34cdf7455137c2b6c705f. 20 September 2019, pkl 11:56 WIB

Kuswarno, E. (2013). Metode Penelitian Komunikasi Fenomenologi:Konsepsi, Pedoman, dan Contoh Penelitian. 
Bandung: Widya Padjajaran.

Littlejohn S. W. \& Karen A. F. (2014). Teori Komunikasi. Jakarta: Salemba Humanika.

Molong, L. J. (2010). Metodologi Penelitian Kualitatif Edisi Revisi. Bandung: PT Remaja Rodakrya.

Mulyana, D. 2018. Metodologi Penelitian Kualitatif, Paradigma Baru Ilmu Komunikasi dan Ilmu Sosial Lainnya. Bandung: Remaja Rosdakarya.

Wan Zulkifli Wan Hasssan, N. (2012). Nafkah Isteri Bekerja: Satu Tinjauan Di Daerah Pasir Mas Kelantan. Jurnal Fiqh, 7(Issue 0).

Paputungan, F., Akhrani, L. A., \& Pratiwi, A. (2013). Kepuasan pernikahan suami yang memiliki istri berkarir. Academia. Edu, 1-19.

Purbasari, D., \& Putri, K. (2015). Pembagian Peran Dalam Rumah Tangga pada pasangan suami istri di jawa. Jurnal Penelitian Humaniora, 16(1), 72-85. https://doi.org/https://doi. org/10.23917/humaniora.v16i1.1523

Sakina, A. I., \& A., D. H. S. (2017). Menyoroti Budaya Patriarki Di Indonesia. Share: Social Work Journal. https://doi. org/10.24198/share.v7i1.13820

Salampessy, A. (2004). Kemampuan Berkomunikasi Suami Isteri Pilar Utama Membangun Keharmonisan Dalam Rumah Tangga. WACANA, Jurnal Ilmiah Ilmu Komunikasi, 2(8),
61-77. http://journal.moestopo.ac.id/ index.php/wacana/article/view/226

Sherlywati, S., Handayani, R., \& Harianti, A. (2017). Analisis Perbandingan Kemampuan Kewirausahaan Pengusaha Perempuan dan Laki-Laki: Studi pada UMKM di Kota Bandung. Jurnal Manajemen Maranatha. https:// doi.org/10.28932/jmm.v16i2.386

Triana, A., \& Krisnani, H. (2018). Peran Ganda Ibu Rumah Tangga Pekerja K31 Unpad Dalam Rangka Menunjang Perekonomian Keluarga. Prosiding Penelitian Dan Pengabdian Kepada Masyarakat. https://doi.org/10.24198/ jppm.v5i2.18370

Tuwu, D. (2018). Peran Pekerja Perempuan Dalam Memenuhi Ekonomi Keluarga: Dari Peran Domestik Menuju Sektor Publik. Al-Izzah: Jurnal Hasil-Hasil Penelitian, 13(1), 63. https://doi. org/10.31332/ai.v13i1.872

Uci Yuliati, M. (2019). The Analyses of Women Role On Part-Time Workers In Junrejo Batu City. Jurnal Perempuan \& Anak (JPA), 2(2), 23-34.

Umar, N. (1999). Argumentasi Kesetaraan Gender: Perspektif al-Qur'an. Jakarta: Paramadina.

Yahaya,A. (2008). Pembentukan Keluarga Yang Bahagia: Cara Membuat Keputusan Dan Cara Mengatasi Masalah Untuk Kecemerlangan Keluarga. Jurnal, 10. 